Article

\title{
The Development of a Menthol Solution for Use during Sport and Exercise
}

\author{
Russ Best ${ }^{1,2, *(\mathbb{D})}$, Iain R. Spears ${ }^{3}$, Philip Hurst ${ }^{4}$ and Nicolas J. A. Berger ${ }^{1,2}$ \\ 1 School of Social Sciences, Humanities \& Law, Teesside University, Middlesbrough TS3 1BX, UK; \\ N.Berger@tees.ac.uk \\ 2 Centre for Sport Science \& Human Performance, WINTEC, Hamilton 3288, New Zealand \\ 3 Pro-Football Support Ltd., Huddersfield HD7 5BQ, UK; iain.spears@gmail.com \\ 4 School of Sport, Exercise \& Rehabilitation Sciences, University of Birmingham, Birmingham B15 2TT, UK; \\ p.hurst@bham.ac.uk \\ * Correspondence: Russell.Best@wintec.ac.nz or R.Best@tees.ac.uk; Tel.: +64-021-129-7900
}

Received: 3 April 2018; Accepted: 7 June 2018; Published: 11 June 2018

\begin{abstract}
Menthol mouth-swilling has been shown to improve performance across differing exercise modalities, yet no work has been conducted to ascertain the preferred concentration of menthol within a swill. Colour has also been shown to influence psychophysiological outcomes, and may influence the efficacy of ergogenic aids. We conducted two experiments: one to ascertain preferred menthol concentration (0.005-0.105\% menthol), the second to assess colour preference (Light Blue, Dark Blue, Light Green, Dark Green, Red). Participants rated swills for Smell, Taste, Freshness, Mouth Feel and Irritation (plus Appearance in the second trial) via $15 \mathrm{~cm}$ Visual Analogue Scales (VAS), having swilled and expectorated $25 \mathrm{~mL}$ of fluid. Both trials employed a crossover design, with tasting order assigned by Latin squares. Differences were assessed for statistical significance $(p<0.05)$ using one-way repeated measures ANOVAs. Standardised mean differences $\pm 90 \%$ confidence intervals were calculated to assess the magnitude of any observed differences. No significant differences were found between concentrations for total VAS score, but higher concentrations demonstrated a greater number of small effects. Similarly, no significant differences between colours were found. Small effects were found when Light Green was compared to Dark Green and Red. Effects were trivial when Light Green was compared to Light Blue $(0.05 \pm 0.20)$ and Dark Blue $(0.19 \pm 0.32)$. We recommend athletes employ a Light Green or Light Blue $0.1 \%$ menthol mouth-swill.
\end{abstract}

Keywords: menthol; exercise; ergogenic aid; mouth swilling

\section{Introduction}

Mouth-swilling strategies may be useful during exercise to alleviate 'dry mouth' brought about by a reduction in salivary flow rate [1]. Other ergogenic effects are likely dependent upon the exercise mode undertaken [2-5] and active ingredients within the swill, e.g., Caffeine [2,6], Carbohydrate [7,8] or Menthol [3]. These ingredients may also be combined with other ergogenic strategies to maximise the influence upon physiological and psychological determinants of fatigue [9-11].

Menthol presents in nature as both a fragrance and flavour molecule, targeting the olfactory and gustatory systems [12,13], typically imparting feelings of coolness and freshness [12-14], hence its seemingly ubiquitous use in consumable products such as confectionary, cosmetics and pharmaceutical applications. A more contemporary application of menthol has been that of an ergogenic aid which can be applied topically [15], used as a mouth swill [16-18] or ingested alongside ice slurry $[9,10,19]$. This use is fitting, with menthol shown to increase the drive to breathe [20], elevate ventilation [21] and attenuate thirst [13], along with eliciting sensations of coolness and freshness that may alleviate 
thermal symptoms during exercise [3]. However, the variability of concentration of menthol within mouth swills and other menthol containing strategies applied to the oral cavity is large. Given such variability, the potential for menthol concentration to affect the efficacy of a treatment, palatability of the menthol solution and any resultant physiological or subjective effects brought about by menthol use is viable. Therefore, an optimal or preferred concentration should be explored.

Similar to concentration, colour has been shown to influence the efficacy of a treatment. For example, studies assessing medical interventions [22], product design [23], solution odour [24] and fictitious sport supplements [25] have reported that the colour of the treatment can significantly influence psychophysiological outcomes. The colour green has been associated with coolness [23,24], tranquilising effects [22] and enhanced endurance performance [25], with blue displaying similar qualities [22-24]. Conversely, red and orange are renowned for stimulatory and warming effects [22,23] but have been shown to decrease motor performance [26]. Such responses are thought to be conditioned through previous experience of colour-associated treatments [22,23], suggesting that previous experience with a coloured product or intervention, may influence participants expectation about the efficacy of that treatment $[22,25]$.

Menthol's novel properties, when coupled with the potential for colour to enhance perceptions of coolness and treatment efficacy, suggest that the development of a menthol solution for experimental application is a process that requires consideration, beyond that of palatability. Therefore, the aims of this study were twofold: (1) to ascertain the preferred concentration of a menthol solution, and (2) to identify preferred colour of a menthol solution. To achieve this, we conducted two separate experiments.

\section{Materials and Methods}

Two repeated measures, post-only crossover design studies were conducted. In study 1, twenty-one participants ( 15 male, 6 female, $26.9 \pm 5.7$ years) were recruited to understand the preferred concentration of menthol. In study 2, thirty-five participants (13 males, 22 females, $22.7 \pm 5.7$ years) were recruited to identify the preferred colour of a menthol solution. Both studies took place in laboratories at $22 \pm 0.3^{\circ} \mathrm{C}$.

Participants in both experiments were excluded if they had any illness that affected their ability to taste or smell, they had anosmia (loss of smell), ageusia (loss of taste), or if they had recently suffered any stomach illnesses such as food poisoning or diarrhoea. Participants were also excluded if they were colour blind. Ethical approval was granted by the School of Social Sciences, Humanities and Law Ethics Committee at Teesside University.

In study 1, menthol crystals ((-)-menthol, Sigma Aldrich, Dorset, UK) were dissolved in ethanol to produce a $5 \%$ menthol solution (i.e., $50 \mathrm{~g}$ menthol per Litre of ethanol). Ethanol was used as a solvent to ensure thorough dilution of menthol throughout the solution, avoiding a film forming or any clumping of partially dissolved menthol crystals. The ethanol-menthol solution was then diluted to the experimental concentrations, using distilled water. Experimental concentrations ranged from 0.005 to $0.105 \%$, in $0.01 \%$ increments. All solutions were colourless/transparent. Participants swilled $25 \mathrm{~mL}$ of menthol solution for $10 \mathrm{~s}$ [16]. They were then asked to rate the solution for Smell, Taste, Mouth Feel, Freshness \& Irritation, using $15 \mathrm{~cm}$ Visual Analogue Scales (VAS). VAS were marked with polarised descriptors 'Unpleasant' and 'Pleasant' at the left and rightmost extremes of each scale, respectively. This process was repeated for each menthol concentration, with tasting order being assigned via an $11 \times 11$ Latin Square, through a custom-made spreadsheet. Water was available ad libitum between tastings. Coffee beans were made available to participants between trials. Inhaling the aroma from the beans provided a contrasting aromatic and olfactory stimulus, with a view to minimising cumulative sensory interference across menthol trials. 
In study 2, coloured versions (light blue, dark blue, light green, dark green and red) of the preferred menthol solution identified in study 1 were tasted to assess the effect of colour on participants' perception of solution characteristics. Dark blue and green colours were achieved by adding $2 \mathrm{~mL}$ of food colouring (Queen Fine Foods Ltd., Alderley, Queensland, Australia) to solution, whereas light blue and green were produced by adding $0.5 \mathrm{~mL}$ of food colouring. The red solution contained $1 \mathrm{~mL}$ of food colouring to be independent of green and blue coloured solutions. Participants repeated the VAS as described in study 1, but in addition, were asked to rate the solutions' Appearance. Tasting order was assigned via a $5 \times 5$ Latin Square, through a custom-made spreadsheet.

Total VAS score (mean \pm standard deviation) per solution was calculated as the sum of the mean scores for each assessed variable, for each concentration and colour. One-way, repeated measures ANOVAs were used to assess the difference in total solution score, between solution concentrations and colour in study 1 and 2, respectively. Checks for normality and variance of the residuals were performed. All analyses were performed using SPSS (v23, IBM, New York, NY, USA). Effect sizes were calculated as standardised mean differences and $90 \%$ Confidence Intervals (C.I.) using a customised spreadsheet [27], with accompanying descriptors [28]. Effect Size thresholds are Trivial $(>0.20)$ Small (0.2-0.6) Medium (0.6-1.2) Large (1.2-2.0) Very Large (>2.0) as per Hopkins and colleagues [28]. Ninety percent (90\%) C.I. are used to differentiate between any observed significant results, and the likely range in which true differences may occur $[28,29]$, rather than as another method of expressing a significant result.

\section{Results}

\subsection{Solution Concentration}

Mauchly's test indicated that sphericity had been violated, $\chi^{2}(54)=94.11, p=0.001$; therefore, a Greenhouse-Geisser $(\varepsilon=0.470)$ correction was applied. There were no significant main differences between menthol mouth swill concentrations, $\mathrm{F}_{(4.695,93.903)}=0.974, p=0.435$. Standardised mean differences are presented in Table 1 . Menthol concentrations of $0.095 \%$ and $0.105 \%$ demonstrated a greater number of Small effects than other concentrations; specifically, demonstrating Small effects with confidence intervals that did not overlap zero, and values for subjective overall perception of $389 \pm 94.73$ and $383.14 \pm 107.22$, respectively (Figure 1; Panel A). Consequently, a $0.10 \%$ solution was used in the colour trial.

\subsection{Solution Colour}

Mauchly's test indicated that sphericity had been violated, $\chi^{2}(9)=24.08, p=0.004$; therefore, a Greenhouse-Geisser $(\varepsilon=0.755)$ correction was applied. No significant differences were observed between mouth swill colours, $\mathrm{F}_{(3.019,11211.266)}=0.835, p=0.479$. Light Green was rated more highly than other solutions (Figure 2), and demonstrated Small differences against Dark Green $(0.28 \pm 90 \%$ CI: 0.33$)$ and Red $(0.24 \pm 0.31)$ but was only trivially different to Dark Blue $(0.19 \pm 0.32)$ and Light Blue $(0.05 \pm 0.20)$ solutions. Light Blue displayed a Small difference when compared to Dark Green $(0.23 \pm 0.38)$, with all other differences considered Trivial (Dark Blue: $0.14 \pm 0.36$; Red: $0.19 \pm 0.32$ ). 

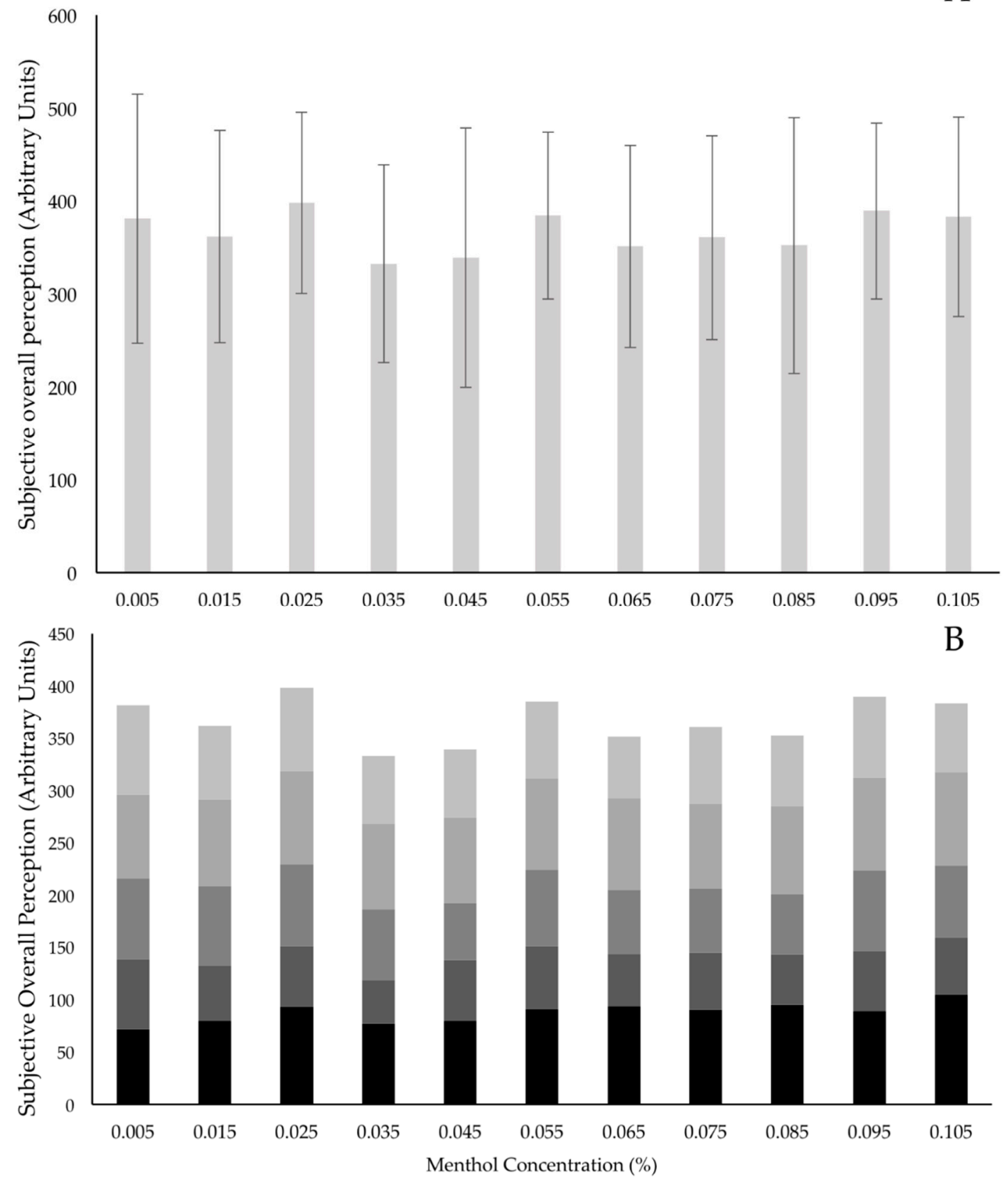

- Smell $\quad$ Taste $\quad$ Mouth Feel $\quad$ Freshness Irritation

Figure 1. Subjective overall preference for each menthol concentration (\%), expressed as Mean VAS rating per solution concentration \pm 1 S.D (Panel A) and as a sum of constituent mean VAS for each reported characteristic (Panel B). 
Table 1. Effect Sizes and accompanying 90\% Confidence Intervals for solution concentrations. Small effects with confidence intervals not overlapping zero are marked with an asterisk $(*)$

\begin{tabular}{|c|c|c|c|c|c|c|c|c|c|c|c|}
\hline 0.005 & 0.015 & 0.025 & 0.035 & 0.045 & 0.055 & 0.065 & 0.075 & 0.085 & 0.095 & 0.105 & \\
\hline $\mathrm{x}$ & $0.27 \pm 0.56$ & $0.03 \pm 0.59$ & $0.52 \pm 0.59$ & $0.49 \pm 0.54$ & $0.16 \pm 0.48$ & $0.44 \pm 0.50$ & $0.29 \pm 0.58$ & $0.41 \pm 0.35 *$ & $0.09 \pm 0.48$ & $0.20 \pm 0.55$ & 0.005 \\
\hline- & $\mathrm{x}$ & $0.29 \pm 0.32$ & $0.24 \pm 0.24$ & $0.19 \pm 0.26$ & $0.20 \pm 0.39$ & $0.09 \pm 0.37$ & $0.01 \pm 0.39$ & $0.08 \pm 0.51$ & $0.23 \pm 0.48$ & $0.17 \pm 0.44$ & 0.015 \\
\hline - & - & $\mathrm{x}$ & $0.24 \pm 0.25$ & $0.19 \pm 0.27$ & $0.19 \pm 0.36$ & $0.08 \pm 0.31$ & $0.01 \pm 0.35$ & $0.08 \pm 0.49$ & $0.24 \pm 0.52$ & $0.19 \pm 0.47$ & 0.025 \\
\hline- & - & - & $\mathrm{x}$ & $0.05 \pm 0.37$ & $0.44 \pm 0.36^{*}$ & $0.16 \pm 0.35$ & $0.25 \pm 0.32$ & $0.41 \pm 0.39$ * & $0.50 \pm 0.48^{*}$ & $0.42 \pm 0.35 *$ & 0.035 \\
\hline - & - & - & - & $\mathrm{x}$ & $0.38 \pm 0.41$ & $0.10 \pm 0.46$ & $0.18 \pm 0.50$ & $0.10 \pm 0.45$ & $0.39 \pm 0.53$ & $0.34 \pm 0.53$ & 0.045 \\
\hline - & - & - & - & - & $\mathrm{x}$ & $0.28 \pm 0.39$ & $0.20 \pm 0.34$ & $0.27 \pm 0.46$ & $0.04 \pm 0.39$ & $0.02 \pm 0.44$ & 0.055 \\
\hline- & - & - & - & - & - & $\mathrm{x}$ & $0.08 \pm 0.30$ & $0.01 \pm 0.53$ & $0.31 \pm 0.43$ & $0.26 \pm 0.33$ & 0.065 \\
\hline - & - & - & - & - & - & - & $\mathrm{x}$ & $0.18 \pm 0.51$ & $0.25 \pm 0.41$ & $0.20 \pm 0.33$ & 0.075 \\
\hline - & - & - & - & - & - & - & - & $\mathrm{x}$ & $0.13 \pm 0.41$ & $0.08 \pm 0.56$ & 0.085 \\
\hline- & - & - & - & - & - & - & - & - & $\mathrm{x}$ & $0.06 \pm 0.44$ & 0.095 \\
\hline- & - & - & - & - & - & - & - & - & - & $\mathrm{x}$ & 0.105 \\
\hline
\end{tabular}




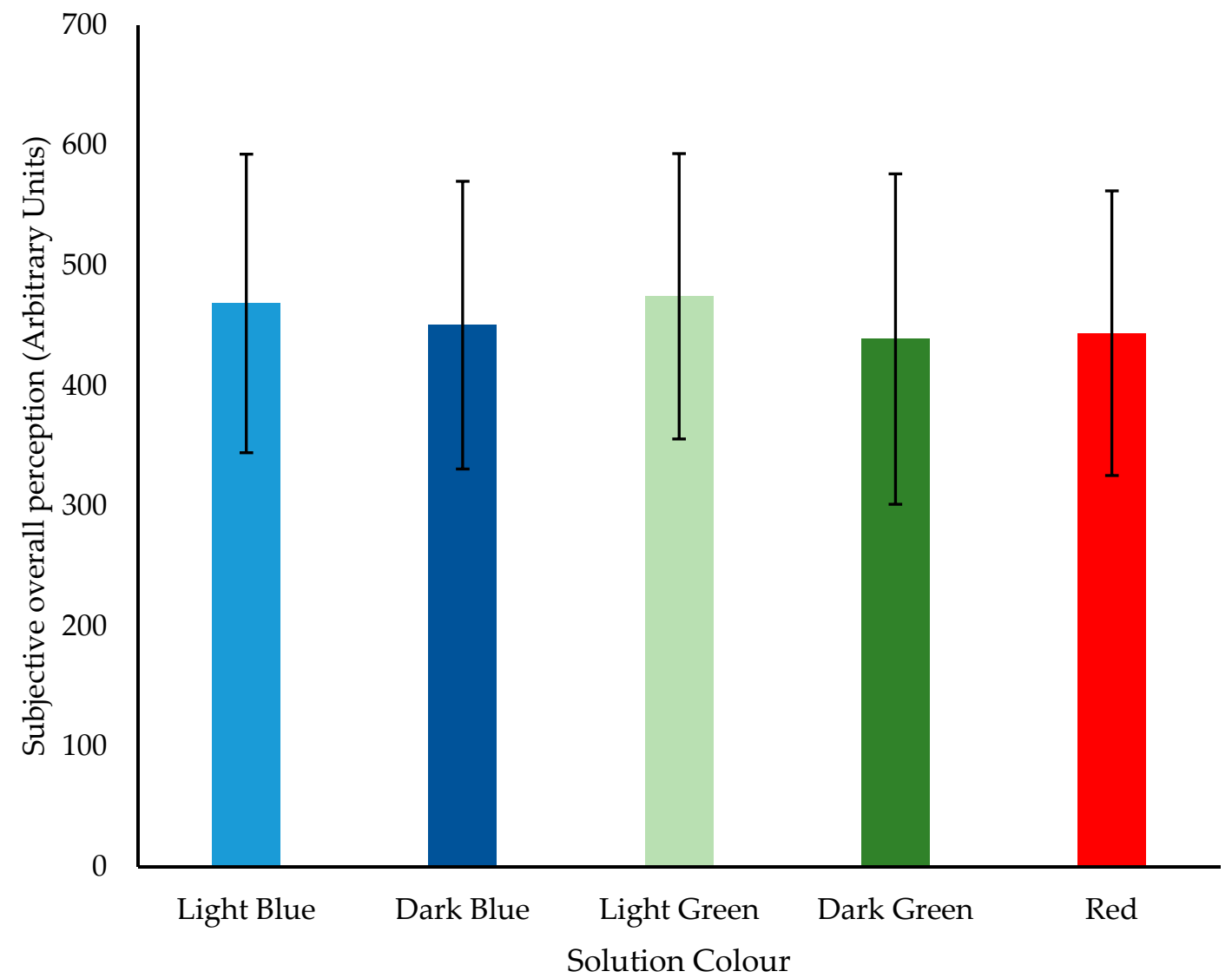

Figure 2. Subjective overall perception (Arbitrary Units) for solution colour, expressed as Mean VAS rating per solution colour \pm 1 S.D.

\section{Discussion}

Menthol mouth swilling is considered a practical ergogenic strategy before and during exercise in hot environments $[11,30]$ and has been used to improve performance during time trials $[17,18]$ and time to exhaustion [16,31]. Perception of menthol mouth swill concentration may be highly individual in nature, with 200 gene variants of the receptor responsible for menthol detection (TRPM8 [32]). This may in part explain the broad standard deviations and confidence intervals overlapping zero in our results.

Perception may be dependent upon physiological factors such as trigeminal chemosensitivity $[33,34]$ and stratum corneum thickness [35], or environmental influences such as previous or habitual exposure to trigeminal agonists [36,37], e.g., regular use of mentholated products. Habitual menthol use may alter the threshold at which TRPM8 channels and the trigeminal nerve are stimulated [37-40], ultimately habituating thermal sensation $[37,38]$. Despite no statistically significant differences in the present investigation, menthol concentrations of $0.095-0.105 \%$ may lead to small increases in trigeminal stimulation, concomitantly conferring benefits such as an increase in ventilation $[3,16]$, reduced thermal sensation [18] and thirst [14], and improved thermal comfort [9] when exposed to the oral cavity.

The possibility that repeated menthol exposure may confer greater benefits than a single dose of menthol has not been directly explored to date. All menthol-containing studies [9,10,16-19,31] have employed a repeated exposure during the exercise bout-this is quantified via time or distance. Better understanding the time course of menthol mouth swilling responses, and the potential impact of concentrations upon these, would provide insight into possible limitations in application for menthol-containing strategies. 
The highest rated solution colour in this investigation (Light Green; $474.40 \pm 118.68$ Arbitrary Units). The Light Blue solution was also rated highly, with trivial effects reported between Light Green and Light Blue (468.49 \pm 124.15 Arbitrary Units; $0.05 \pm 0.20$ Trivial). Menthol-containing products such as mouth-wash, confectionary and other oral hygiene products are associated with these colours [41,42], and subjective qualities of solution may be enhanced due to this association $[23,24,43]$. In the absence of significant results between solution colours, researchers may consider using a light green or light blue coloured solution as a starting point for future menthol research.

The perception of colour and concentration may be influenced via the environment in which the solution is administered. The present study was conducted in an ambient temperature laboratory $\left(22 \pm 0.3^{\circ} \mathrm{C}\right)$, which may have enhanced the subjective qualities of the menthol solution(s). For example, blue and green are typically associated with cooling [23,24], participants may have therefore perceived these colours as more refreshing than red, which is associated with warming [22,23]. Future research should aim to understand the perception of concentration and colour under differing environmental conditions; especially those conditions that are below $8{ }^{\circ} \mathrm{C}$ or exceed $28{ }^{\circ} \mathrm{C}$. These temperatures represent threshold values for the menthol receptor TRMP8 [44], and the human thermoneutral zone $\left(\geq 28^{\circ} \mathrm{C}[11,45,46]\right)$. Investigations at the upper limit of, or exceeding this range are greater than the temperature at which the rate of metabolic heat production exceeds the rate of thermal transfer to the environment $\left(25^{\circ} \mathrm{C}\right.$ [47]). This provides an important platform from which to study the perceptual and physiological responses to menthol mouth swilling during exercise. The mode (e.g., running or cycling [48,49]) and nature (continuous or interval; [50]) of exercise are also important experimental concerns, due to differences in heat production, heat storage, and hyperthermia risk [49].

Practically, the effect of colour extends beyond the aesthetic qualities of a solution or treatment; treatment colour may impart emotional modifications that could be tailored to an athlete's psychological profile. Red is typically associated with high arousal states [51,52], anger [53] and danger [54]; red has also been associated with Tae Kwando match outcome [55]. Conversely, blue and green are perceived as calming [22], only slightly arousing [52], and in congruence with our findings have been shown to be perceived as more pleasant than red [52]. Recently, a green inert drink was used to facilitate an induced beliefs investigation into sprint performance [56]. The colour green was chosen specifically in this investigation due to the potency of belief around green substances' abilities to enhance performance $[25,56]$. Such expectancy cannot be ignored in our investigation, or the practical application(s) of its findings. Furthermore, perceptions and preferences of colour, vary between individuals, within groups and across cultures [57]. Colours can be interpreted as having opposing meanings in different countries and cultures [58], but in multi-cultural individuals have been reported to be interpreted intermediately [59], careful consideration of cultural perceptions would further enhance the implementation of our findings.

\section{Conclusions}

Based upon the results of our study, we recommend athletes and practitioners work together to ascertain a menthol concentration for mouth swilling. This concentration would ideally be based upon an individual's perception of the characteristics assessed in this work, and their competitive and training environment(s). Similarly, for practitioners, we advise using a light blue or green solution as a starting point for further investigation, given the synonymy with menthol containing products, but acknowledge that other cultural factors may influence this decision.

Author Contributions: R.B., N.J.A.B. and I.R.S. conceived and designed the experiments; R.B. performed the experiments; R.B. and N.J.A.B. analysed the data; R.B., N.J.A.B., I.R.S. and P.H. wrote the paper.

Acknowledgments: The authors would like to thank Paul Douglas for his work in ensuring design and preparation of the solution was carried out safely and successfully.

Conflicts of Interest: The authors declare no conflict of interest. 


\section{References}

1. Dawes, C. Physiological factors affecting salivary flow rate, oral sugar clearance, and the sensation of dry mouth in man. J. Dent. Res. 1987, 66, 648-653. [CrossRef] [PubMed]

2. Beaven, C.M.; Maulder, P.; Pooley, A.; Kilduff, L.; Cook, C. Effects of caffeine and carbohydrate mouth rinses on repeated sprint performance. Appl. Physiol. Nutr. Metab. 2013, 38, 633-637. [CrossRef] [PubMed]

3. Stevens, C.J.; Best, R. Menthol: A fresh ergogenic aid for athletic performance. Sports Med. 2017, 47, 1035-1042. [CrossRef] [PubMed]

4. Peart, D.J. Quantifying the Effect of Carbohydrate Mouth Rinsing on Exercise Performance. J. Strength Cond. Res. 2017, 31, 1737-1743. [CrossRef] [PubMed]

5. Clarke, N.D.; Kornilios, E.; Richardson, D.L. Carbohydrate and Caffeine Mouth Rinses Do Not Affect Maximum Strength and Muscular Endurance Performance. J. Strength Cond. Res. 2015, 29, 2926-2931. [CrossRef] [PubMed]

6. Doering, T.M.; Fell, J.W.; Leveritt, M.D.; Desbrow, B.; Shing, C.M. The effect of a caffeinated mouth-rinse on endurance cycling time-trial performance. IJSNEM 2014, 24, 90-97. [CrossRef] [PubMed]

7. Burke, L.M.; Maughan, R.J. The Governor has a sweet tooth-Mouth sensing of nutrients to enhance sports performance. Eur. J. Sport Sci. 2014, 15, 29-40. [CrossRef] [PubMed]

8. Stellingwerff, T.; Cox, G.R. Systematic review: Carbohydrate supplementation on exercise performance or capacity of varying durations 1. Appl. Physiol. Nutr. Metab. 2014, 39, 998-1011. [CrossRef] [PubMed]

9. Riera, F.; Trong, T.T.; Sinnapah, S.; Hue, O. Physical and Perceptual Cooling with Beverages to Increase Cycle Performance in a Tropical Climate. PLoS ONE 2014, 9, e103718. [CrossRef] [PubMed]

10. Tran Trong, T.; Riera, F.; Rinaldi, K.; Briki, W.; Hue, O. Ingestion of a cold temperature/menthol beverage increases outdoor exercise performance in a hot, humid environment. PLoS ONE 2015, 10, e0123815. [CrossRef] [PubMed]

11. Best, R.; Payton, S.; Spears, I.; Riera, F.; Berger, N. Topical and Ingested Cooling Methodologies for Endurance Exercise Performance in the Heat. Sports 2018, 6, 11. [CrossRef]

12. Eccles, R. Menthol and Related Cooling Compounds. J. Pharm. Pharmacol. 1994, 46, 618-630. [CrossRef] [PubMed]

13. Eccles, R. Role of cold receptors and menthol in thirst, the drive to breathe and arousal. Appetite 2000, 34, 29-35. [CrossRef] [PubMed]

14. Eccles, R.; Du-Plessis, L.; Dommels, Y.; Wilkinson, J.E. Cold pleasure. Why we like ice drinks, ice-lollies and ice cream. Appetite 2013, 71, 357-360. [CrossRef] [PubMed]

15. Gillis, D.J.; Barwood, M.J.; Newton, P.S.; House, J.R.; Tipton, M.J. The influence of a menthol and ethanol soaked garment on human temperature regulation and perception during exercise and rest in warm, humid conditions. J. Therm. Biol. 2016, 58, 99-105. [CrossRef] [PubMed]

16. Mündel, T.; Jones, D.A. The effects of swilling an $1(-)$-menthol solution during exercise in the heat. Eur. J. Appl. Physiol. 2009, 109, 59-65. [CrossRef] [PubMed]

17. Stevens, C.J.; Bennett, K.J.M.; Sculley, D.V.; Callister, R.; Taylor, L.; Dascombe, B.J. A comparison of mixed-method cooling interventions on pre-loaded running performance in the heat. J. Strength Cond. Res. 2016, 1-28.

18. Stevens, C.J.; Thoseby, B.; Sculley, D.V.; Callister, R.; Taylor, L.; Dascombe, B.J. Running performance and thermal sensation in the heat are improved with menthol mouth rinse but not ice slurry ingestion. J. Appl. Physiol. 2016, 26, 1209-1216. [CrossRef] [PubMed]

19. Riera, F.; Trong, T.; Rinaldi, K.; Hue, O. Precooling does not Enhance the Effect on Performance of Midcooling with Ice-Slush/Menthol. Int. J. Sports Med. 2016, 37, 1025-1031. [CrossRef] [PubMed]

20. Eccles, R. Menthol: Effects on nasal sensation of airflow and the drive to breathe. Curr. Allergy Asthma Rep. 2003, 3, 210-214. [CrossRef] [PubMed]

21. Meamarbashi, A.; Rajabi, A. The effects of peppermint on exercise performance. J. Int. Soc. Sports Nutr. 2013, 10, 15. [CrossRef] [PubMed]

22. De Craen, A.J.M.; Roos, P.J.; de Vries, A.L.; Kleijnen, J. Effect of colour of drugs: Systematic review of perceived effect of drugs and of their effectiveness. BMJ 1996, 313, 1624-1626. [CrossRef] [PubMed]

23. Fenko, A.; Schifferstein, H.N.J.; Hekkert, P. Looking hot or feeling hot: What determines the product experience of warmth? Mater. Des. 2010, 31, 1325-1331. [CrossRef] 
24. Michael, G.A.; Rolhion, P. Cool colors: Color-induced nasal thermal sensations. Neurosci. Lett. 2008, 436, 141-144. [CrossRef] [PubMed]

25. Szabo, A.; Bérdi, M.; Köteles, F.; Bárdos, G. Perceptual characteristics of nutritional supplements determine the expected effectiveness in boosting strength, endurance, and concentration performances. IJSNEM 2013, 23, 624-628. [CrossRef] [PubMed]

26. Briki, W.; Rinaldi, K.; Riera, F.; Trong, T.T.; Hue, O. Perceiving red decreases motor performance over time: A pilot study. Rev. Eur. Psychol. Appl./Eur. Rev. Appl. Psychol. 2015, 65, 301-305. [CrossRef]

27. Hopkins, W.G. Spreadsheet for analysis of controlled trials with adjustment for a predictor. Sportscience 2006, 10, 46-50.

28. Hopkins, W.G.; Marshall, S.W.; Batterham, A.M.; Hanin, J. Progressive Statistics for Studies in Sports Medicine and Exercise Science. Med. Sci. Sports Exerc. 2009, 41, 3-13. [CrossRef] [PubMed]

29. Sterne, J.A.C.; Smith, G.D. Sifting the evidence-what's wrong with significance tests? Phys. Ther. 2001, 81, 1464-1469. [CrossRef] [PubMed]

30. Stevens, C.J.; Taylor, L.; Dascombe, B.J. Cooling During Exercise: An Overlooked Strategy for Enhancing Endurance Performance in the Heat. Sports Med. 2016, 47, 829-841. [CrossRef] [PubMed]

31. Flood, T.R.; Waldron, M.; Jeffries, O. Oral L-menthol reduces thermal sensation, increases work-rate and extends time to exhaustion, in the heat at a fixed rating of perceived exertion. Eur. J. Appl. Physiol. 2017, 117, 1501-1512. [CrossRef] [PubMed]

32. Morgan, K.; Sadofsky, L.R.; Morice, A.H. Genetic variants affecting human TRPA1 or TRPM8 structure can be classified in vitro as 'well expressed', 'poorly expressed' or 'salvageable'. Biosci. Rep. 2015, 35, e00255. [CrossRef] [PubMed]

33. Frasnelli, J.; Albrecht, J.; Bryant, B.; Lundström, J.N. Perception of specific trigeminal chemosensory agonists. Neuroscience 2011, 189, 377-383. [CrossRef] [PubMed]

34. Michlig, S.; Merlini, J.M.; Beaumont, M.; Ledda, M.; Tavenard, A.; Mukherjee, R.; Camacho, S.; le Coutre, J. Effects of TRP channel agonist ingestion on metabolism and autonomic nervous system in a randomized clinical trial of healthy subjects. Nat. Publish. Group 2016, 17. [CrossRef] [PubMed]

35. Watson, H.R.; Hems, R.; Rowsell, D.G.; Spring, D.J. New compounds with the menthol cooling effect. J. Soc. Cosmet. Chem. 1978, 29, 185-200.

36. Cliff, M.A.; Green, B.G. Sensitization and desensitization to capsaicin and menthol in the oral cavity: Interactions and individual differences. Physiol. Behav. 1996, 59, 487-494. [CrossRef]

37. Gillis, D.J.; Weston, N.; House, J.R.; Tipton, M.J. Influence of repeated daily menthol exposure on human temperature regulation and perception. Physiol. Behav. 2015, 139, 511-518. [CrossRef] [PubMed]

38. Botonis, P.G.; Geladas, N.D.; Kounalakis, S.N.; Cherouveim, E.D.; Koskolou, M.D. Effects of menthol application on the skin during prolonged immersion in swimmers and controls. J. Appl. Physiol. 2016, 27, 1560-1568. [CrossRef] [PubMed]

39. Klein, A.H.; Carstens, M.I.; Zanotto, K.L.; Sawyer, C.M.; Ivanov, M.; Cheung, S.; Carstens, E. Self- and Cross-desensitization of Oral Irritation by Menthol and Cinnamaldehyde (CA) via Peripheral Interactions at Trigeminal Sensory Neurons. Chem. Senses 2010, 36, 199-208. [CrossRef] [PubMed]

40. Kalantzis, A.; Robinson, P.P.; Loescher, A.R. Effects of capsaicin and menthol on oral thermal sensory thresholds. Arch. Oral Biol. 2007, 52, 149-153. [CrossRef] [PubMed]

41. Spence, C. Just how much of what we taste derives from the sense of smell? Flavour 2015, 1-10. [CrossRef]

42. Shankar, M.U.; Levitan, C.A.; Spence, C. Grape expectations: The role of cognitive influences in color-flavor interactions. Conscious. Cogn. 2010, 19, 380-390. [CrossRef] [PubMed]

43. Yu, L.; Westland, S.; Li, Z.; Pan, Q.; Shin, M.J.; Won, S. The role of individual colour preferences in consumer purchase decisions. Color Res. Appl. 2017, 43, 258-267. [CrossRef]

44. Patel, T.; Ishiuji, Y.; Yosipovitch, G. Menthol: A refreshing look at this ancient compound. J. Am. Acad. Dermatol. 2007, 57, 873-878. [CrossRef] [PubMed]

45. Bligh, J.; Johnson, K.G. Glossary of terms for thermal physiology. J. Appl. Physiol. 1973, 35, 941-961. [CrossRef] [PubMed]

46. Cabanac, M.; Massonnet, B. Thermoregulatory responses as a function of core temperature in humans. J. Physiol. 1977, 265, 587-596. [CrossRef] [PubMed]

47. Kenny, G.P.; Jay, O. Thermometry, calorimetry, and mean body temperature during heat stress. Compr. Physiol. 2013, 3, 1689-1719. [PubMed] 
48. Junge, N.; Jørgensen, R.; Flouris, A.D.; Nybo, L. Prolonged self-paced exercise in the heat-Environmental factors affecting performance. Temperature 2016, 3, 539-548. [CrossRef] [PubMed]

49. Mora-Rodriguez, R.; Ortega, J.F.; Hamouti, N. In a hot-dry environment racewalking increases the risk of hyperthermia in comparison to when running at a similar velocity. Eur. J. Appl. Physiol. 2011, 111, 1073-1080. [CrossRef] [PubMed]

50. Mora-Rodriguez, R.; Del Coso, J.; Estevez, E. Thermoregulatory responses to constant versus variable-intensity exercise in the heat. Med. Sci. Sports Exerc. 2008, 40, 1945-1952. [CrossRef] [PubMed]

51. Dreiskaemper, D.; Strauss, B.; Hagemann, N.; Büsch, D. Influence of red jersey color on physical parameters in combat sports. J. Sport Exerc. Psychol. 2013, 35, 44-49. [CrossRef] [PubMed]

52. Briki, W.; Hue, O. How Red, Blue, and Green are Affectively Judged. Appl. Cognit. Psychol. 2016, 30, 301-304. [CrossRef]

53. Fetterman, A.K.; Robinson, M.D.; Gordon, R.D.; Elliot, A.J. Anger as Seeing Red. Soc. Psychol. Pers. Sci. 2010, 2, 311-316. [CrossRef] [PubMed]

54. Young, S.G.; Elliot, A.J.; Feltman, R.; Ambady, N. Red enhances the processing of facial expressions of anger. Emotion 2013, 13, 380-384. [CrossRef] [PubMed]

55. Falcó, C.; Conchado, A.; Estevan, I. The Effect of Color on the Use of Electronic Body Protectors in Taekwondo Matches. Percept. Mot. Skills 2016, 122, 812-824. [CrossRef] [PubMed]

56. De la Vega, R.; Alberti, S.; Ruíz-Barquín, R.; Soós, I.; Szabo, A. Induced beliefs about a fictive energy drink influences 200-m sprint performance. Eur. J. Sport Sci. 2017, 17, 1084-1089.

57. Taylor, C.; Clifford, A.; Franklin, A. Color preferences are not universal. J. Exp. Psychol. Gen. 2013, 142, 1015-1027. [CrossRef] [PubMed]

58. Al-Rasheed, A.S. An experimental study of gender and cultural differences in hue preference. Front. Psychol. 2015, 30, 1-5. [CrossRef] [PubMed]

59. Yokosawa, K.; Schloss, K.B.; Asano, M.; Palmer, S.E. Ecological Effects in Cross-Cultural Differences Between U.S. and Japanese Color Preferences. Cogn. Sci. 2016, 40, 1590-1616. [CrossRef] [PubMed]

(C) 2018 by the authors. Licensee MDPI, Basel, Switzerland. This article is an open access article distributed under the terms and conditions of the Creative Commons Attribution (CC BY) license (http:/ / creativecommons.org/licenses/by/4.0/). 